\title{
The increasing cost of the basic foods required to promote health in Queensland
}

Michelle S Harrison, Terry Coyne, Amanda J Lee, Dympna Leonard, Simone Lowson, Anita Groos and Bronwyn A Ashton

$\mathrm{D}$ iet quality varies with social status, and this contributes to health inequalities. ${ }^{1}$ There is evidence that retail food prices are higher in rural and remote localities than urban areas throughout Australia, and this may have negative nutrition and health consequences. ${ }^{2-8}$

The 2004 Healthy Food Access Basket (HFAB) survey was the fourth biennial statewide cross-sectional survey of the costs and availability of a standard basket of basic

Location and Australian Bureau of Statistics remoteness classifications ${ }^{11,12}$ for the 97 stores in the 2004 Healthy Food Access Basket survey

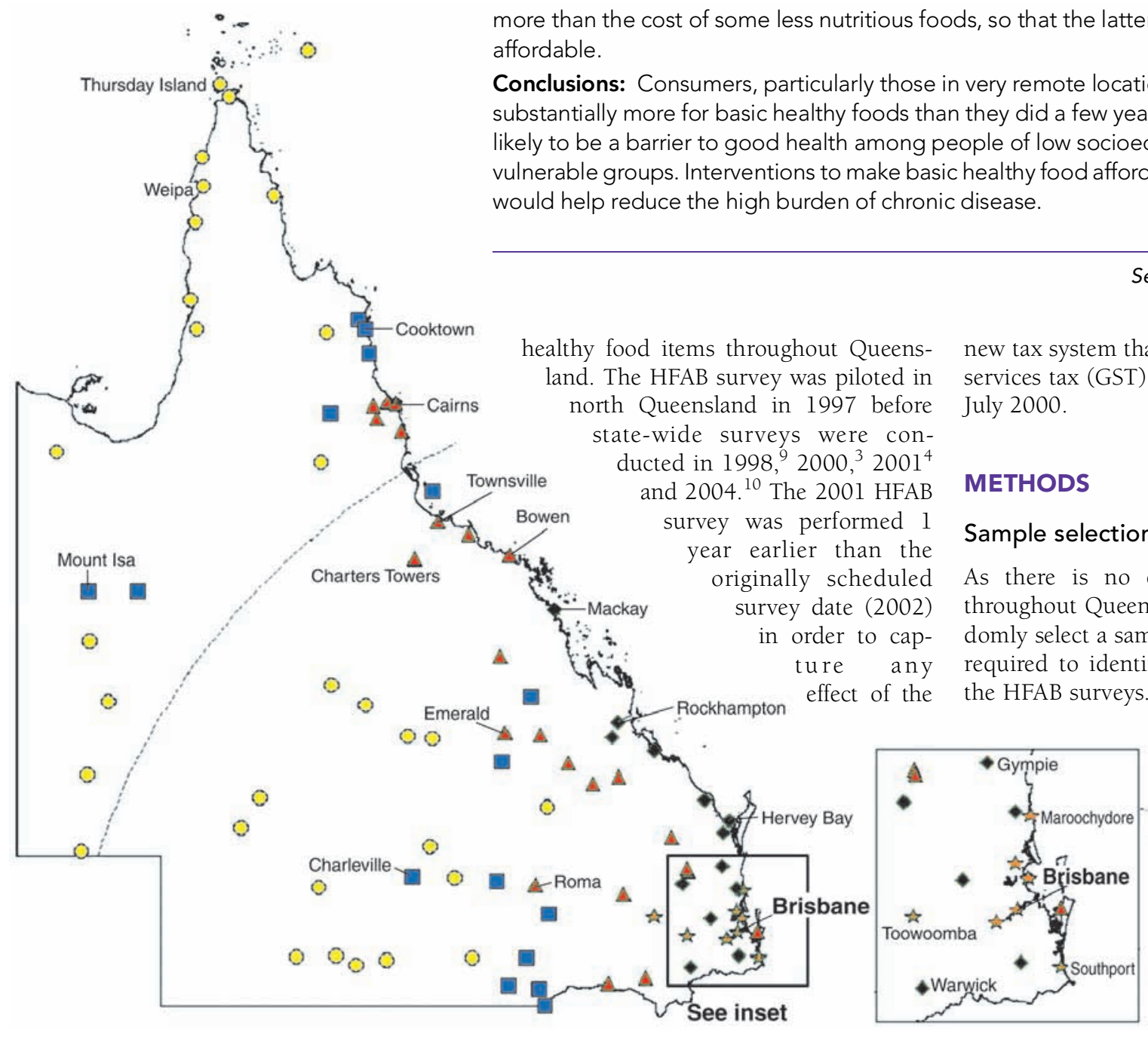

MJA • Volume 186 Number 1 • 1 January 2007

\section{ABSTRACT}

Objective: To assess changes in the cost and availability of a standard basket of healthy food items (the Healthy Food Access Basket [HFAB]) in Queensland over time.

Design and participants: A series of four cross-sectional surveys (in 1998, 2000, 2001 and 2004) describing the cost and availability of foods in the HFAB over time. In the latest survey, 97 Queensland food stores across the five Australian Bureau of Statistics remoteness categories were compared.

Main outcome measures: Cost comparisons for HFAB items by remoteness category for the 97 stores surveyed in 2004; changes in cost and availability of foods in the 81 stores surveyed since 2000; comparisons of food prices in the 56 stores surveyed in 1998, 2000, 2001 and 2004.

Results: In 2004, the Queensland mean cost of the HFAB was $\$ 395.28$ a fortnight. The cost of the HFAB was $29.6 \%$ (\$113.89) higher in "very remote" areas than in "major cities" $(P<0.001)$. Between 2001 and 2004, the Queensland mean cost of the HFAB increased by $14.0 \%(\$ 48.45)$, while in very remote areas the cost increased by $18.0 \%(\$ 76.93)(P<0.001)$. Since 2000, the annualised per cent increase in cost of the HFAB has been higher than the increase in Consumer Price Index for food in Brisbane. The cost of healthy foods has risen more than the cost of some less nutritious foods, so that the latter are now relatively more ffordable. vulnerable groups. Interventions to make basic healthy food affordable and accessible to all MJA 2007; 186: 9-14

See also page 7 and page 15 healthy food items throughout Queensnd. The HFAB survey was piloted in state-wide surveys were conate-wide surveys were conducted in $1998,{ }^{9} 2000,{ }^{3} 2001^{4}$ and 2004. ${ }^{10}$ The $2001 \mathrm{HFAB}$ urvey was performed 1 ear earlier than the (2002) rvey date (2002) order to capture any effect of the new tax system that included the goods and services tax (GST), which commenced on 1 July 2000

\section{METHODS}

\section{Sample selection}

database of food stores throughout Queensland from which to randomly select a sample, local knowledge was required to identify stores for inclusion in the HFAB surveys. The largest food store in

\begin{tabular}{|l|}
\hline Remoteness legend \\
Inner regional \\
Outer regional \\
Remote \\
Very remote \\
$1500 \mathrm{~km}$ road distance \\
from Brisbane
\end{tabular}


NUTRITION AND OBESITY - RESEARCH

\begin{tabular}{|c|c|c|c|c|c|}
\hline Basket item & Unit size & Total amount in HFAB & Basket item & Unit size & $\begin{array}{c}\text { Total amount in } \\
\text { HFAB }\end{array}$ \\
\hline \multicolumn{3}{|l|}{ Dairy group } & \multicolumn{3}{|l|}{ Bread and cereals group } \\
\hline Fresh full-cream milk & $2 \mathrm{~L}$ & $8 \mathrm{~L}$ & White bread & $680 \mathrm{~g}$ & $6800 \mathrm{~g}$ \\
\hline Fresh reduced-fat milk & $1 \mathrm{~L}$ & $1 \mathrm{~L}$ & Wholemeal bread & $680 \mathrm{~g}$ & $6800 \mathrm{~g}$ \\
\hline Powdered full-cream milk & $1 \mathrm{~kg}$ & $1 \mathrm{~kg}$ & White flour & $2 \mathrm{~kg}$ & $2.5 \mathrm{~kg}$ \\
\hline Powdered skim milk & $1 \mathrm{~kg}$ & $1 \mathrm{~kg}$ & Wholemeal flour & $1 \mathrm{~kg}$ & $2.5 \mathrm{~kg}$ \\
\hline Long-life full-cream milk & $1 \mathrm{~L}$ & $4 \mathrm{~L}$ & Weetbix & $750 \mathrm{~g}$ & $1500 \mathrm{~g}$ \\
\hline Cheese & $500 \mathrm{~g}$ & $500 \mathrm{~g}$ & Rolled oats & $1 \mathrm{~kg}$ & $750 \mathrm{~g}$ \\
\hline \multicolumn{3}{|c|}{ Fruit, vegetables and legumes group } & White rice & $1 \mathrm{~kg}$ & $5 \mathrm{~kg}$ \\
\hline Apples & $1 \mathrm{~kg}$ & $6 \mathrm{~kg}$ & Tinned spaghetti & $420-425 \mathrm{~g}$ & $1275 \mathrm{~g}$ \\
\hline Oranges & $1 \mathrm{~kg}$ & $11 \mathrm{~kg}$ & Instant noodles & $85 \mathrm{~g}$ & $1020 \mathrm{~g}$ \\
\hline Bananas & $1 \mathrm{~kg}$ & $5 \mathrm{~kg}$ & Sao biscuits & $250 \mathrm{~g}$ & $1 \mathrm{~kg}$ \\
\hline Tinned fruit salad in natural juice & $400-450 \mathrm{~g}$ & $3520 \mathrm{~g}$ & \multicolumn{3}{|l|}{ Meat and meat alternatives group } \\
\hline Orange juice (100\%) & $2 \mathrm{~L}$ & $4 \mathrm{~L}$ & Tinned corned beef & $340 \mathrm{~g}$ & $340 \mathrm{~g}$ \\
\hline Tomatoes & $1 \mathrm{~kg}$ & $5 \mathrm{~kg}$ & Tinned meat and onion/vegetables & $400-425 \mathrm{~g}$ & $820 \mathrm{~g}$ \\
\hline Potatoes & $1 \mathrm{~kg}$ & $10 \mathrm{~kg}$ & Beef mince & $1 \mathrm{~kg}$ & $1 \mathrm{~kg}$ \\
\hline Pumpkin & $1 \mathrm{~kg}$ & $1.5 \mathrm{~kg}$ & Rump steak & $1 \mathrm{~kg}$ & $1 \mathrm{~kg}$ \\
\hline Cabbage & half & $1.5 \mathrm{~kg}$ & Frozen chicken & size 14 & $2 \mathrm{~kg}$ \\
\hline Lettuce & whole & 1.5 & Tinned smoked oysters & $85-105 \mathrm{~g}$ & $170 \mathrm{~g}$ \\
\hline Carrots & $1 \mathrm{~kg}$ & $2 \mathrm{~kg}$ & Large eggs ( $\min 50 \mathrm{~g})$ & $700 \mathrm{~g}$ & $1320 \mathrm{~g}$ \\
\hline Onions & $1 \mathrm{~kg}$ & $2 \mathrm{~kg}$ & Sausages & $1 \mathrm{~kg}$ & $1 \mathrm{~kg}$ \\
\hline Frozen vegetables & $500 \mathrm{~g}$ & $2.5 \mathrm{~kg}$ & Tinned ham & $450 \mathrm{~g}$ & $1 \mathrm{~kg}$ \\
\hline Tinned peas & $420-440 \mathrm{~g}$ & $880 \mathrm{~g}$ & \multicolumn{3}{|l|}{ Non-core foods } \\
\hline Tinned baked beans & $420-425 \mathrm{~g}$ & $1700 \mathrm{~g}$ & Unsaturated margarine & $500 \mathrm{~g}$ & $1500 \mathrm{~g}$ \\
\hline \multirow[t]{2}{*}{ Tinned beetroot } & $425-450 \mathrm{~g}$ & $450 \mathrm{~g}$ & White sugar & $2 \mathrm{~kg}$ & $3 \mathrm{~kg}$ \\
\hline & & & Canola oil & $750 \mathrm{~mL}$ & $750 \mathrm{~mL}$ \\
\hline
\end{tabular}

*Consisting of a man (> 19 years), a woman (> 19 years), an older woman (>61 years), a teenage boy (14 years), a girl (8 years) and a boy (4 years).

the largest town(s) in each of the 38 Queensland health service districts was selected, in order to reflect prices paid by the majority of the community. Where possible, the same stores were included in 1998 and each successive survey, but for any store that later closed or no longer wished to participate, an alternative store in the same town or a nearby location was included.

Selected stores were categorised by the Australian Bureau of Statistics remoteness structure $^{11}$ and using the updated Accessibility/Remoteness Index of Australia $(\text { ARIA }+)^{12}$ by populated localities as the basis for the definition of remoteness (see map, page 9). ARIA+ defines localities in terms of remoteness of geographical location as well as access to services.

In the 1998, 2000 and 2001 HFAB surveys, there were 111,92 and 88 stores, respectively. In 2004, 102 stores agreed to participate (100\% response rate). However, only 97 were included in the current analysis, as four surveys arrived too late and one survey was lost in the mail.
The Healthy Food Access Basket

The range and type of foods included in the HFAB represent commonly available and popular foods selected to provide $70 \%$ of the nutritional requirements and $95 \%$ of the estimated energy requirements of a "reference family" of six people over a 2 -week period (Box 1). ${ }^{13}$

Basic healthy foods in the HFAB include bread and cereals; fruit, vegetables and legumes; meat and meat alternatives; dairy foods; and limited amounts of some energy-dense foods (margarine, oil and sugar). The quantities of food included in the HFAB are based on model B of the core food groups. ${ }^{13}$ For comparative purposes, two takeaway foods ( $190 \mathrm{~g}$ meat pie, $375 \mathrm{~mL}$ cola beverage) and two tobacco items ( $50 \mathrm{~g}$ tobacco, pack of 25 cigarettes) were also surveyed (they are referred to as "unhealthy" items in our analysis). Information about missing HFAB items was also collected. Only missing items for the total basket from stores surveyed from 2000 to 2004 were compared.
Data were collected on-site by Queensland Health nutritionists and health workers during April and May in 1998, 2000 and 2004. In 2001, the data collection period extended into June.

Stores were not advised of the specific date and time of surveys, so that results reflect usual availability and cost for consumers. Details relating to selection of brands and sizes of food items are described elsewhere. ${ }^{3}$

\section{Cost comparisons}

The cost of the total HFAB; the fruit, vegetables and legumes in the basket; and the unhealthy items were compared by remoteness category for the 97 stores surveyed in 2004. Changes in cost and availability of foods since the previous two surveys (2000 and 2001) were also analysed by remoteness category for the 81 stores that were included in all three surveys. Further comparisons of food prices were made for the 56 stores that were included in all four surveys (1998, 2000, 2001 and 2004), and increases were com- 
pared with increase in the Consumer Price Index (CPI) for food in Brisbane over the same period. ${ }^{14}$ Because the usual store stocking practices for ham and cabbage changed after the 1998 survey, the total basket could only be compared from 2000 onwards.

The CPI for food is based on a wide range of commonly purchased items (including soft drinks, cakes, biscuits, confectionery, takeaway foods and fast foods), several of which incur the GST. Basic food items (such as those in the HFAB) that are required to support and maintain health are mostly exempt from this tax. All CPI figures, including price data for individual foods used to calculate the CPI, are available for capital cities only.

\section{Data analysis}

Data were analysed using SPSS for Windows version 12.0.1 (SPSS Inc, Chicago, Ill, USA). For missing items, the mean price for the item in the corresponding remoteness category was used as the default price for that year. The differences in mean costs of the HFAB contents across remoteness categories were assessed by one-way analysis of variance. The differences in mean costs over time were assessed by paired $t$ tests. The trend differences in means were assessed using Kendall's tau $(\tau)$.

To compare changes between consecutive HFAB surveys, only the stores previ- ously surveyed were included. As the time intervals between the four successive HFAB surveys were different, the results were "annualised" to allow for comparable time frames for assessing price change. This was done by calculating the square root of the price difference between the 1998 and 2000 surveys, and the cube root of the price difference between the 2001 and 2004 surveys.

\section{RESULTS}

\section{Costs by remoteness category}

The 2004 HFAB survey results show a trend of increasing food prices with increasing remoteness category (Box 2). In the "very remote" category, the cost of the HFAB was 29.6\% (\$113.89) higher than in the "major cities" category, and the cost of fruit, vegetables and legumes was 20.3\% (\$32.34) higher. Furthermore, there were significant differences within the very remote category. For very remote stores $>1500 \mathrm{~km}$ from Brisbane $(n=16)$, the cost of the total HFAB was $13.2 \%$ (\$61.69) higher and the cost of fruit, vegetables and legumes 18.8\% (\$32.91) higher than in very remote stores $<1500 \mathrm{~km}$ from Brisbane $(n=16)$ (see map). The cost disparity across remoteness categories for the unhealthy items was less than for the $\mathrm{HFAB}$, with the cost of takeaway and tobacco items in the very remote category being $14.2 \%$ (\$4.47) higher than in the major cities category $(P<0.001)$.

There were significant differences in the cost of items in all basic healthy food groups $^{13}$ by remoteness category. The differences between remoteness categories were greater for the "bread and cereals" and "dairy" groups than for the "fruit" and the "vegetables and legumes" groups (Box 2).

\section{Cost increases over time}

There has been an increase in the price of basic healthy food in the 81 stores that were surveyed in 2000, 2001 and 2004 (Box 3). Between the 2001 and 2004 surveys, the Queensland average price of the HFAB increased by $14.0 \%(\$ 48.45)$. The cost of the HFAB increased significantly more in very remote areas $(18.0 \%, \$ 76.93)$ compared with major cities (13.2\%, \$44.96, $P<0.001$ ).

On an annual basis, the increase in the Queensland average price of the HFAB between 2001 and 2004 (4.5\%, \$16.15 per year) was minor compared with the $12.0 \%$ (\$36.98) increase experienced for the HFAB between 2000 and 2001.

State-wide, the price of fruit, vegetables and legumes in the basket increased by 17.9\% (\$24.98) between 2001 and 2004 (Box 3). Differences in the price of fruit, vegetables and legumes in the basket across the remoteness categories were not as great

\section{Mean cost $(95 \% \mathrm{Cl})$ of the Healthy Food Access Basket (HFAB) and basic healthy food groups in the 97 stores surveyed in} 2004, by remoteness category ${ }^{*+11,12}$

\begin{tabular}{|c|c|c|c|c|c|c|c|}
\hline & $\begin{array}{l}\text { Queensland } \\
\qquad(n=97)\end{array}$ & $\begin{array}{c}\text { Major cities } \\
\quad(n=7)\end{array}$ & $\begin{array}{l}\text { Inner regional } \\
\text { areas }(n=14)\end{array}$ & $\begin{array}{l}\text { Outer regional } \\
\text { areas }(n=25)\end{array}$ & $\begin{array}{l}\text { Remote areas } \\
\quad(n=19)\end{array}$ & $\begin{array}{l}\text { Very remote } \\
\text { areas }(n=32)\end{array}$ & $\begin{array}{l}\%(\$) \text { increase in mear } \\
\text { cost from major citie } \\
\text { to very remote areas }\end{array}$ \\
\hline$\overline{\mathrm{HFAB}(\$)}$ & $\begin{array}{c}395.28 \\
(395.25-395.31)\end{array}$ & $\begin{array}{c}384.74 \\
(360.32-409.16)\end{array}$ & $\begin{array}{c}392.18 \\
(382.51-401.85)\end{array}$ & $\begin{array}{c}412.02 \\
(399.82-424.22)\end{array}$ & $\begin{array}{c}441.21 \\
(426.89-455.54)\end{array}$ & $\begin{array}{c}498.63 \\
(480.57-516.68)\end{array}$ & $29.60 \%(\$ 113.89)^{\S}$ \\
\hline $\begin{array}{l}\text { Fruit, vegetables } \\
\text { and legumes }(\$)\end{array}$ & $\begin{array}{c}164.58 \\
(164.56-164.61)\end{array}$ & $\begin{array}{c}159.42 \\
(134.08-184.76)\end{array}$ & $\begin{array}{c}166.25 \\
(156.32-176.18)\end{array}$ & $\begin{array}{c}174.35 \\
(164.82-183.88)\end{array}$ & $\begin{array}{c}177.87 \\
(169.82-185.92)\end{array}$ & $\begin{array}{c}191.76 \\
(181.80-201.73)\end{array}$ & $20.30 \%(\$ 32.34)^{\S}$ \\
\hline Bread and cereals $(\$)$ & $\begin{array}{c}91.34 \\
(91.33-91.35)\end{array}$ & $\begin{array}{c}87.94 \\
(86.56-89.32)\end{array}$ & $\begin{array}{c}89.99 \\
(87.55-92.43)\end{array}$ & $\begin{array}{c}96.18 \\
(90.84-101.51)\end{array}$ & $\begin{array}{c}108.68 \\
(102.56-114.80)\end{array}$ & $\begin{array}{c}128.11 \\
(122.73-133.49)\end{array}$ & $45.68 \%(\$ 40.17)^{\S}$ \\
\hline Dairy foods (\$) & $\begin{array}{c}52.03 \\
(52.02-52.03)\end{array}$ & $\begin{array}{c}50.50 \\
(48.32-52.69)\end{array}$ & $\begin{array}{c}51.35 \\
(49.95-52.76)\end{array}$ & $\begin{array}{c}54.17 \\
(52.01-56.34)\end{array}$ & $\begin{array}{c}59.91 \\
(56.94-62.88)\end{array}$ & $\begin{array}{c}69.15 \\
(66.46-71.84)\end{array}$ & $36.93 \%(\$ 18.65)^{\S}$ \\
\hline $\begin{array}{l}\text { Meat and meat } \\
\text { alternatives }(\$)\end{array}$ & $\begin{array}{c}74.71 \\
(74.70-74.71)\end{array}$ & $\begin{array}{c}75.24 \\
(74.02-76.46)\end{array}$ & $\begin{array}{c}71.15 \\
(68.25-74.05)\end{array}$ & $\begin{array}{c}73.75 \\
(71.06-76.43)\end{array}$ & $\begin{array}{c}78.92 \\
(75.64-82.20)\end{array}$ & $\begin{array}{c}90.44 \\
(86.83-94.04)\end{array}$ & $20.20 \%(\$ 15.20)^{\S}$ \\
\hline Fruit (\$) & $\begin{array}{c}88.14 \\
(88.12-88.15)\end{array}$ & $\begin{array}{c}84.56 \\
(70.04-99.08)\end{array}$ & $\begin{array}{c}87.90 \\
(82.41-93.38)\end{array}$ & $\begin{array}{c}97.24 \\
(91.02-103.46)\end{array}$ & $\begin{array}{c}95.99 \\
(90.54-101.45)\end{array}$ & $\begin{array}{c}103.95 \\
(98.29-109.62)\end{array}$ & $22.93 \%(\$ 19.39)^{\S}$ \\
\hline $\begin{array}{l}\text { Vegetables and } \\
\text { legumes (\$) }\end{array}$ & $\begin{array}{c}76.45 \\
(76.43-76.46)\end{array}$ & $\begin{array}{c}74.86 \\
(63.19-86.53)\end{array}$ & $\begin{array}{c}78.36 \\
(72.62-84.10)\end{array}$ & $\begin{array}{c}77.11 \\
(72.45-81.77)\end{array}$ & $\begin{array}{c}81.87 \\
(76.20-87.55)\end{array}$ & $\begin{array}{c}87.81 \\
(81.38-94.24)\end{array}$ & $17.30 \%(\$ 12.95)^{\Uparrow}$ \\
\hline $\begin{array}{l}\text { "Unhealthy" } \\
\text { items }{ }^{\ddagger}(\$)\end{array}$ & $\begin{array}{c}32.05 \\
(32.05-32.05)\end{array}$ & $\begin{array}{c}31.47 \\
(30.75-32.20)\end{array}$ & $\begin{array}{c}32.00 \\
(31.15-32.85)\end{array}$ & $\begin{array}{c}33.09 \\
(32.43-33.76)\end{array}$ & $\begin{array}{c}34.70 \\
(33.28-36.13)\end{array}$ & $\begin{array}{c}35.94 \\
(34.55-37.33)\end{array}$ & $14.20 \%(\$ 4.47)^{\S}$ \\
\hline
\end{tabular}

*Weighting proportional to Queensland population size by each remoteness category. † Source: Healthy Food Access Basket survey $2004 .{ }^{10} \ddagger$ "Unhealthy" items:

$190 \mathrm{~g}$ meat pie, $375 \mathrm{~mL}$ cola beverage, $50 \mathrm{~g}$ tobacco, pack of 25 cigarettes. $\S$ Kendall's $\tau<0.001$. ๆ Kendall's $\tau=0.006$. 


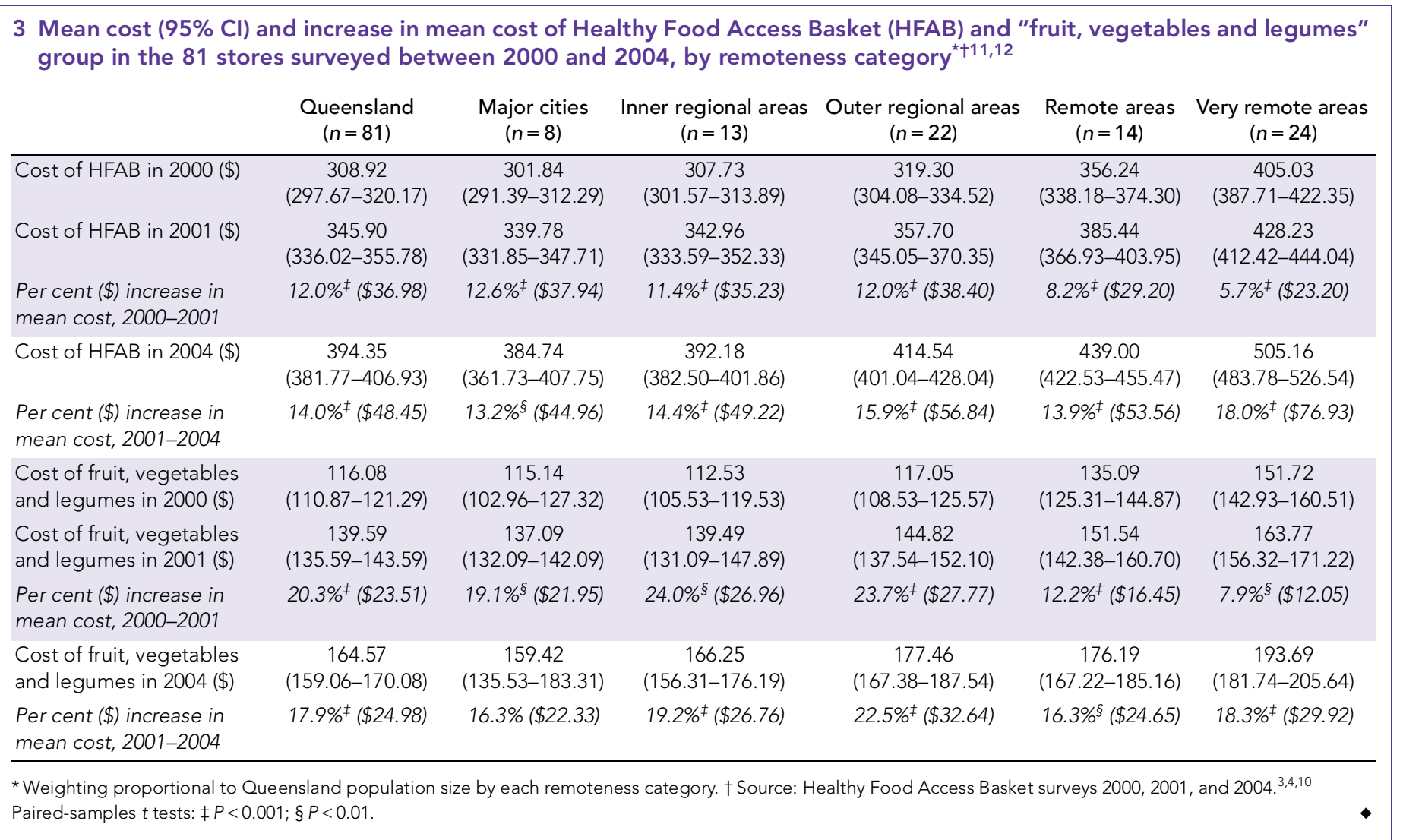

as those seen for the total HFAB. Within the fruit, vegetables and legumes group, price increases were greatest for fruit.

Annualised per cent increases in costs for the 56 stores surveyed from 1998 to 2004 compared with changes in the CPI for food in Brisbane over the same period are shown in Box 4. The most dramatic change in food costs was between 2000 and 2001. The introduction of the GST may be one factor contributing to the increase in CPI for food in Queensland during that time. ${ }^{15}$ The price changes in the CPI for food in Brisbane were very similar to those found for Australia as a whole. ${ }^{14}$

\section{Availability}

Basic healthy food items are less likely to be available in "outer regional", "remote" and "very remote" areas (Box 5), with almost $11 \%$ of HFAB food items not available for purchase in stores in remote and very remote areas in 2004 . The most frequently missing HFAB items (in descending order) were wholemeal flour, powdered skim milk, frozen chicken, wholemeal bread, 100\% fruit juice, bananas, tinned ham, rolled oats, fresh reduced-fat milk, cabbage and longlife full-cream milk.

\section{DISCUSSION}

While the higher price increases for the HFAB in more remote areas raise concern about food access and availability for good health, the overall substantial price increases experienced in all five remoteness categories raise a potential barrier to healthy food access for all Queenslanders. This is particularly the case for people of low socioeconomic status and other vulnerable groups, such as Indigenous people, who are known to suffer a greater burden of ill health than other Australians. ${ }^{16}$ Higher prices may be a barrier to healthy eating that can compromise nutritional and health status and add to the burden of obesity and chronic disease. ${ }^{17}$ Earlier studies have identified poor food and health knowledge and undeveloped cooking and budgeting skills as additional barriers to good health. ${ }^{8}$ Various environmental influences, including food access, contribute to the higher death rates experienced by people from more socioeconomically disadvantaged and remote areas. ${ }^{18}$

The cost burden is further highlighted by the higher prices paid by the very remote communities located further than $1500 \mathrm{~km}$ from Brisbane. Transportation costs, in addition to double handling of produce through secondary wholesalers, contribute to this cost disparity. In addition, retailers are unable to achieve economies of scale due to the relatively small number of consumers and higher overheads.

Our analysis of a small number of unhealthy items suggests that their price is less affected by remoteness than the HFAB items. One explanation may be that these less healthy products are more robust and more profitable, so the extra cost of providing these items in remote locations can be absorbed by the store.

While a number of reports have stated that the effect of the introduction of the GST was mainly captured in the September 2000 quarter, ${ }^{15,19}$ they do not explain the substantial cost increases for basic food items between 2000 and 2001 - costs that were actually predicted to fall with the introduction of the GST. ${ }^{20}$ With steady or declining farmers' prices and little or no impact of drought on retail prices at the time, it has been suggested that other factors, including retailing issues, contributed to these cost increases. ${ }^{21}$

Despite a "stabilisation" in CPI for food in Brisbane over the financial year 200304, the HFAB cost increase has continued to be higher than the CPI for food across all 


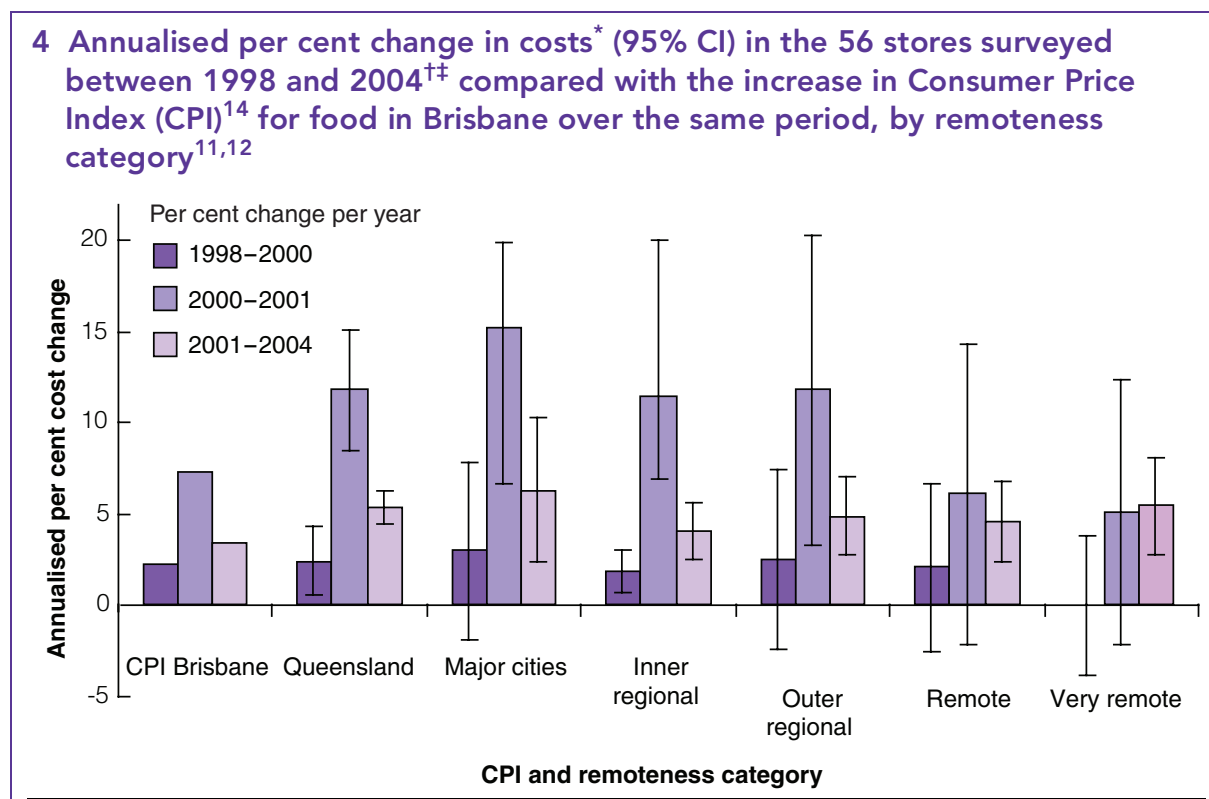

* Ham and cabbage excluded. † Weighting proportional to Queensland population size by each remoteness category. $¥$ Source: Healthy Food Access Basket surveys 1998, 2000, 2001 and 2004. 3,4,9,10

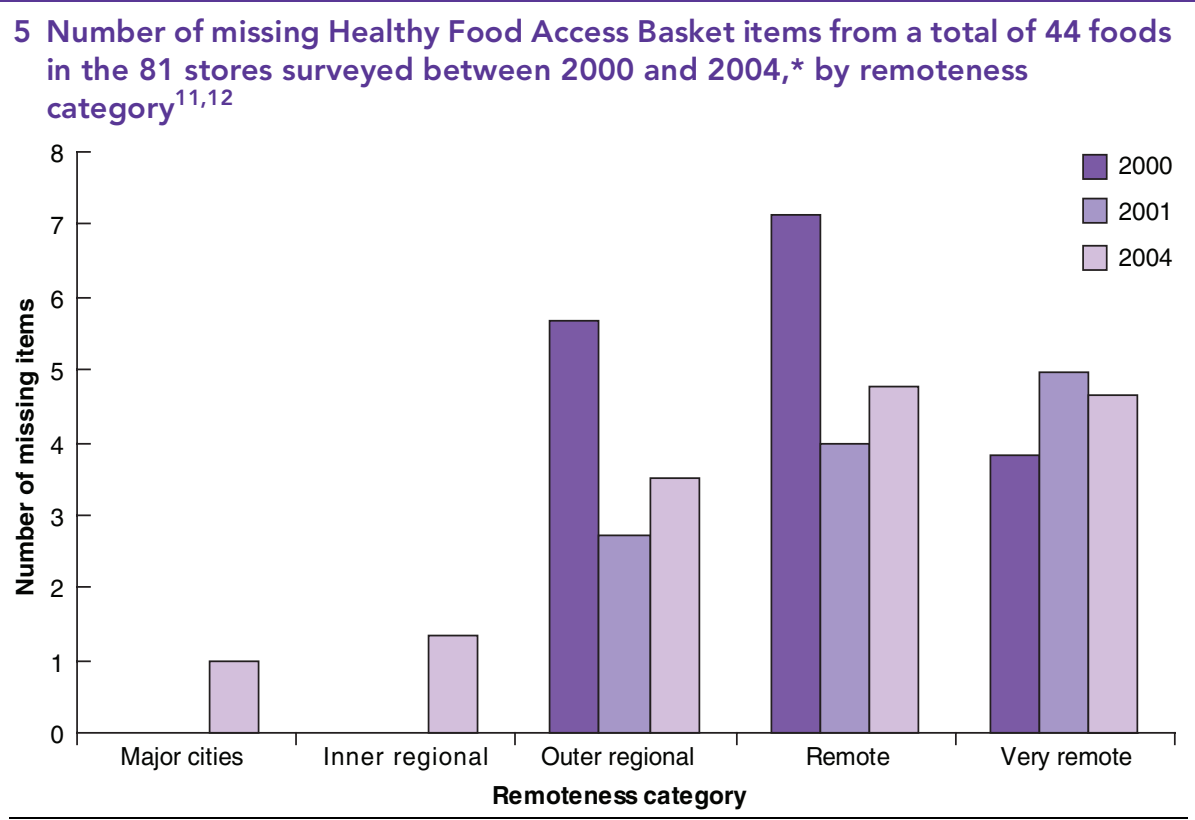

*Source: Healthy Food Access Basket surveys 2000, 2001 and 2004. 3,4,10

remoteness categories for the 56 stores surveyed from 1998 to 2004 (Box 4). This suggests that the cost for basic foods necessary to achieve good health has become, and continues to be, more expensive than less nutritious alternatives, as included in the basket to calculate the CPI for food. The price gap between healthy and unhealthy foods has also been illustrated in the United States ${ }^{17}$ and France. ${ }^{22}$ With between items not available on the day and those never stocked, time delays in restocking sold-out lines may have an impact on consumer access to healthy foods that could put some individuals at increased nutritional and health risk.

Factors affecting the price, availability and quality of food supply are complex and exist at local, state and national levels. There needs to be an investigation to identify these factors, so that strategies can be developed to improve affordability and access to healthy food for all Queenslanders.

\section{COMPETING INTERESTS}

Our research was funded by Queensland Health.

\section{AUTHOR DETAILS}

Michelle S Harrison, BSc, GradDipDiet, MPH, Senior Public Health Nutritionist ${ }^{1}$

Terry Coyne, BSc, MSc, PhD, Senior Lecturer ${ }^{2}$ Amanda J Lee, BSc(Nutr), PostGradDipDiet, PhD, Principal Public Health Nutritionist ${ }^{1}$

Dympna Leonard, BSc(Diet), MPH, Director of Public Health Nutrition ${ }^{3}$

Simone Lowson, BAppSc(Nutr),

PostGradDipDiet, MPH, Director of Public Health Nutrition ${ }^{4}$

Anita Groos, BSc(Hons), MSc, DrOecTroph,

Director of Public Health Nutrition ${ }^{5}$

Bronwyn A Ashton, BHMS(Ed),

GradDipNutrDiet, MMedSc, Senior Public Health Nutritionist ${ }^{1}$

1 Health Promotion Unit, Population Health Branch, Queensland Health, Brisbane, QLD.

2 School of Population Health, University of Queensland, Brisbane, QLD.

3 Tropical Population Health Network,

Queensland Health, Cairns, QLD.

4 Southern Area Population Health Service,

Queensland Health, Brisbane, QLD.

5 Central Area Population Health Service,

Queensland Health, Brisbane, QLD.

Correspondence:

michelles_harrison@health.qld.gov.au

\section{REFERENCES}

1 World Health Organization. Social determinants of health: the solid facts. 2nd ed. Geneva: WHO, 2003.

2 Queensland Treasury. Index of retail prices in regional centres. Brisbane: Office of Economic and Statistical Research, Queensland Treasury, 2001

3 Queensland Health. The 2000 Healthy Food Access Basket (HFAB) survey. Brisbane: Queensland Health, 2001. http:// www.health.qld.gov.au/phs/documents/shpu/ 9137.pdf (accessed Sep 2006).

4 Queensland Health. The 2001 Healthy Food Access Basket (HFAB) survey. Brisbane: Queensland Health, 2003. http:// www.health.qld.gov.au/phs/Documents/shpu/ 21629.pdf (accessed Sep 2006). 


\section{NUTRITION AND OBESITY — RESEARCH}

5 Northern Territory Government Department of Health and Community Services. Market basket survey of remote community stores in the Northern Territory April-June 2002. Darwin: Nutrition and Physical Activity Unit, Department of Health and Community Services, 2002.

6 Meedeniya J, Smith A, Carter P. Food supply in rural South Australia: a survey of food cost, quality and variety. Adelaide: Department of Human Services, 2000.

7 Burns C, Gibbons P, Boak R, et al. Food cost and availability in a rural setting in Australia. Rural Remote Health [Internet] 2004; 4: 311. http://rrh.deakin.edu.au/articles/subviewnew.asp?ArticlelD=311 (accessed Sep 2006).

8 Sullivan H, Gracey M, Hevron V. Food costs and nutrition of Aborigines in remote areas of northern Australia. Med J Aust 1987; 147: 334 337.

9 Queensland Health. The 1998 Healthy Food Access Basket (HFAB) survey. Cairns: Queensland Health, 1999.

10 Queensland Health. The 2004 Healthy Food Access Basket (HFAB) survey. Brisbane: Queensland Health, 2005. http://
www.health.qld.gov.au/phs/Documents/shpu/ 30605.pdf (accessed Nov 2006).

11 Australian Bureau of Statistics. Information paper: outcomes of $A B S$ views on remoteness consultation, Australia. Canberra: ABS, 2001.

12 GISCA, University of Adelaide. ARIA+ version 2: Accessibility/Remoteness Index of Australia. Adelaide: University of Adelaide, 2004. http:// www.gisca.adelaide.edu.au/products_services/ ariav2.html (accessed Sep 2006).

13 Cashel K, Jeffreson S. The core food groups. Canberra: National Health and Medical Research Council, 1992.

14 Australian Bureau of Statistics. Quarterly CPI publication (June quarter 1998-2004). Canberra: ABS, October 1998-July 2004. (ABS Cat. No. 6455.0.40.001.)

15 Australian Bureau of Statistics. Special article measuring the impact of the new tax system on the September quarter 2000 Consumer Price Index. Canberra: ABS, 2000. (ABS Cat. No. 1350.0.)

16 Australian Institute of Health and Welfare. Rural, regional and remote health: mortality trends 1992-2003. Canberra: AlHW, 2006. (AIHW Cat. No. PHE 71.)
17 Drewnowski A, Darmon N. The economics of obesity: dietary energy density and energy cost. Am J Clin Nutr 2005; 82 Suppl: S265-S273.

18 Queensland University of Technology and Australian Institute of Health and Welfare. Health inequalities in Australia: mortality. Canberra: QUT and AIHW, 2004

19 Australian Competition and Consumer Commission. GST final report: ACCC oversight of pricing responses to the introduction of the new tax system. Canberra: ACCC Publishing Unit, 2003.

20 Australian Competition and Consumer Commission. Report on ACCC price surveys: general survey. Canberra: ACCC Publishing Unit, 2001.

21 Spencer S. Price determination in the Australian food industry: a report. Canberra: Australian Government Department of Agriculture, Fisheries and Forestry, 2004.

22 Andrieu E, Darmon N, Drewnowski A. Low-cost diets: more energy, fewer nutrients. Eur J Clin Nutr 2006; 60: 434-436

23 Queensland Department of Primary Industries. Queenslanders' attitudes toward everyday food items. Newsletter. Brisbane: DPI, 2001

(Received 10 May 2006, accepted 19 Sep 2006) 